\title{
REVIEW
}

\section{Cell transplantation therapy for diabetes mellitus: endocrine pancreas and adipocyte}

\author{
Junji Fujikura ${ }^{1)}$, Kiminori Hosoda ${ }^{2)}$ and Kazuwa Nakao ${ }^{1)}$ \\ 1) Division of Endocrinology and Metabolism, Kyoto University Hospital, Kyoto 606-8507, Japan \\ ${ }^{2)}$ Department of Human Health Science, Kyoto University Graduate School of Medicine, Kyoto 606-8507, Japan
}

\begin{abstract}
Experimental transplantation of endocrine tissues has led to significant advances in our understanding of endocrinology and metabolism. Endocrine cell transplantation therapy is expected to be applied to the treatment of metabolic endocriopathies. Restoration of functional pancreatic beta-cell mass or of functional adipose mass are reasonable treatment approaches for patients with diabetes or lipodystrophy, respectively. Human induced pluripotent stem (iPS) cell research is having a great impact on life sciences. Doctors Takahashi and Yamanaka discovered that the forced expression of a set of genes can convert mouse and human somatic cells into a pluripotent state $[1,2]$. These iPS cells can differentiate into a variety of cell types. Therefore, iPS cells from patients may be a potential cell source for autologous cell replacement therapy. This review briefly summarizes the current knowledge about transplantation therapy for diabetes mellitus, the development of the endocrine pancreas and adipocytes, and endocrine-metabolic disease-specific iPS cells.
\end{abstract}

Key words: Transplantation, Diabetes mellitus, Pancreas, Adipocyte, Development

\section{Transplantation in endocrinology}

In 1683, Conrad Brunner (1653-1727) removed the pancreas from a dog and noted the resulting polydipsia and polyuria, two hallmark symptoms of diabetes [3]. In 1889, Oscar Minkowski (1858-1931) transplanted canine pancreases into pancreatectomized dogs and noticed a decrease in the severity in the symptoms. This experiment demonstrated that the pancreas is responsible for the regulation of blood glucose [4]. The first recorded human pancreatic xenotransplantation was performed in 1893. Minkowski transplanted pieces of freshly slaughtered sheep's pancreas into a diabetic 15-year-old boy; however, the boy died three days after the operation. Concern about the detrimental effects of exocrine acinar cells on graft function and viability has stimulated the development of islet cell isolation and transplantation procedures.

In addition to research on diabetes mellitus, transplantation experiments involving other tissues and

Submitted Apr. 18, 2013; Accepted May 14, 2013 as EJ13-0162

Released online in J-STAGE as advance publication May 29, 2013

Correspondence to: Junji Fujikura, M.D., Ph.D., Division of Endocrinology and Metabolism, Kyoto University Hospital, 54 Shogoin-Kawahara-cho, Sakyo-ku, Kyoto 606-8507, Japan.

E-mail: j-fuji@sannet.ne.jp organs have increased our understanding of endocrinology. In 1849, Adolph Berthold (1803-1861) reported on the transplantation of testes in cockerels [3]. He transplanted testes from young cockerels into the abdominal cavity of the castrated cockerels and found that the recipients continued to retain the normal secondary sexual characteristics. Moritz Schiff (1823-1896) showed that intra-abdominal transplantation of the thyroid gland could prevent the fatal results of total thyroidectomy [5]. George Murray (1865-1939) provided the first account of a human patient with myxedema given substitution with subcutaneous thyroid tissues, which had a beneficial effect [6]. Early in the 20th century, several investigators showed that transplantation of the parathyroid gland prevented the development of neuromuscular symptoms in parathyroidectomized animals [7].

These studies suggested that endocrine cells may be suitable for transplantation, because they are individual functional units that sense extracellular stimuli and secrete hormones.

\section{Pancreas and islet transplantation in diabetes mellitus}

The pancreas plays a key role in the maintenance of nutritional homeostasis through its exocrine and endo- 
crine functions. The exocrine acini secrete digestive enzymes (amylase, lipase, and protease) into the duodenum through ducts, and the endocrine cells in the islets produce peptide hormones, which maintain a balance between anabolism and catabolism. Endocrine beta-cell secrete insulin and amylin; alpha-cells secrete glucagon; delta-cells secrete somatostatin; PP-cells secrete pancreatic polypeptide; and epsilon-cells secrete ghrelin [8].

Type 1 diabetes mellitus (T1DM) is characterized by absolute insulin deficiency induced by the autoimmune destruction of pancreatic beta-cells. Type 2 diabetes mellitus (T2DM) is characterized by relative insulin deficiency, in which insulin secretion is insufficient to overcome insulin resistance. Beta-cell function is estimated to decrease by about $50 \%$ at the onset of T2DM [9]. Recent genome-wide association studies have identified nearly 75 susceptibility loci associated with T2DM, most of which are thought to be associated with beta-cell failure [10,11]. Thus, deficits in functional beta-cell mass are commonly recognized in both types of diabetes $(\sim 99 \%$ deficit in long-standing T1DM, 40-60\% deficit in long-standing T2DM) [12-15].

Insulin therapy is the only treatment for T1DM; however, the restoration of physiological insulin secretion by insulin injection is difficult to achieve, and results in unstable glucose levels. Better glycemic control has to be related to more frequent hypoglycemia in both T1DM and T2DM [16-18]. Most adults with T1DM in the USA have been HbA1c level higher than $7.5 \%$, and the mean HbAlc level in Japanese diabetic patients is also high (T1DM, 8.2\%; T2DM, $7.4 \%$ ) [19]. Therefore, the restoration of a functional beta-cell mass is the logical and most effective treatment for diabetes mellitus.
Pancreas transplantation is currently the only known therapy for T1DM that reliably establishes a long-term euglycemic state [20]. It is effective in that patients remain insulin independent for more than 10 years [21]. After transplantation, the normal glucagon response to hypoglycemia is restored, and hypoglycemic episodes are uncommon [22]. However, transplantation requires major surgery and has a surgical complication (repeat laparotomy) rate between $10 \%$ and $20 \%$ [23].

Pancreatic islet transplantation is safe and reproducible. In this procedure, isolated islets are embolized into the liver through a catheter placed into the main portal vein of the recipient. However, insulin independence rarely extends beyond two years [24-27]. The necessary immunosuppressive regimen, including a calcineurin inhibitor or mTOR inhibitor, and the process of islet isolation itself may contribute to the low islet viability [28-30]. Both pancreas and islet transplantation require immunosuppressive therapy, carry the threat of recurrence of autoimmunity, and are limited by donor shortages [31-35].

Patient-derived induced pluripotent stem (iPS) cells may provide an unlimited supply of transplantable cells for beta-cell replacement therapy in diabetic patients. Autotransplantation avoids the risks associated with allograft rejection and the need for immunosuppressants. Previous studies have demonstrated clearly that the most efficient and reproducible method to generate a given cell type from stem cells is to recapitulate embryonic development in vitro [36, 37]. This would be the case for both the endocrine pancreas (Fig. 1) and adipocytes $[38,39]$. Further understanding of the developmental processes enables us to design more robust and reliable differentiation protocols for the treatment of diabetes mellitus.

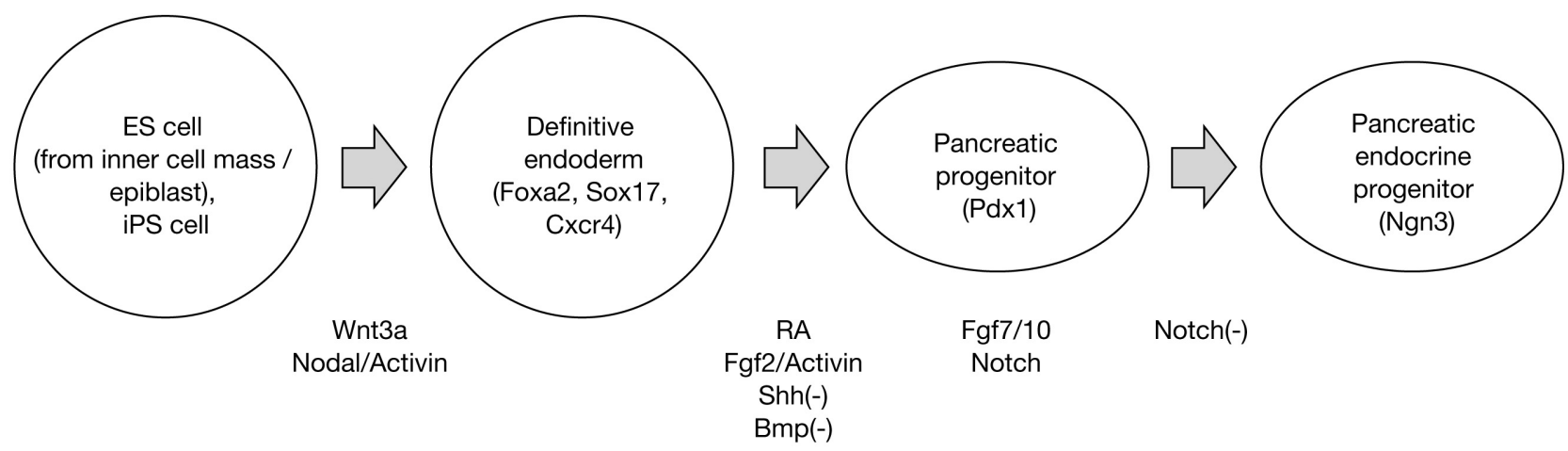

Fig. 1 Simplified representation of the signaling pathways regulating pancreatic development 


\section{Endocrine pancreatic development}

\section{Endodermal origin of the pancreas}

The origin of pancreatic endocrine cells from the neuroectoderm (neural crest) was proposed around 1970 [40]. Pancreatic endocrine cells and neurons share common biochemical properties, morphological features, and molecules; for example, neuron-specific enolase, synaptophysin, chromogranin A, Pax4, Pax6, NeuroD, Nkx2.2, Nkx6.1, Isl1, MafB, and MafA [41, 42]. However, fate-mapping studies using quailchick chimeras provided evidence against a neuroectoderm origin for pancreatic endocrine cells [43-45]. Furthermore, ex vivo organ culture experiments demonstrated that a rat embryo without the neurectoderm can form a normal pancreas, indicating that all types of pancreatic cells are derived from endoderm progenitors [46].

\section{Definitive endoderm (DE) formation}

The endoderm is divided into two types: the visceral endoderm (VE), which derives directly from the inner cell mass; and the other is the DE [47]. The VE forms the yolk sac but rarely contributes to the embryo proper [48-51]. The DE forms during gastrulation, when DE progenitors ingress into the anterior primitive streak and migrate into and replace the VE layer. The DE and VE share common transcription factors such as Foxa2 and Sox17, but only the DE expresses chemokine receptor (Cxcr)-4 [52]. Wnt/beta-catenin signaling is detected in the primitive streak [53]. Wnt3- or beta-cateninknockout mice lack a primitive streak [54, 55]. Nodal, a TGF-beta family member, is expressed in the anterior primitive streak and is required for the specification of the anterior DE [56, 57]. Induction of DE differentiation from embryonic stem (ES)/iPS cells is accomplished by adding TGF-beta ligands (Nodal, Activin A) and either Wnt molecules (Wnt3a) or a GSK3-beta inhibitor [52, 58-63].

\section{Pancreatic specification}

During organogenesis, the DE forms the epithelial lining of the primitive gut tube from which the digestive tract, thyroid, liver, and pancreas develop [64]. The pancreas develops from the ventral and dorsal buds of the endoderm expressing the pancreatic-duodenal homeobox gene (Pdx1) [65]. In the Pdx1-knockout mouse, the pancreas fails to develop beyond the bud stage $[66,67]$.
The retinoic acid (RA)-synthesizing enzyme, retinaldehyde dehydrogenase 2 (Raldh2), is expressed in the somitic mesoderm dorsal to the primitive gut tube. Raldh2-knockout mice lack expression of Pdx1 in the dorsal endoderm, but administration of RA rescues the loss of Pdx1 expression [68, 69]. Treatment of ES cellderived endoderm cells with RA induces the expression of Pdx1 as well as other important transcription factors, such as pancreatic transcription factor-1a and neurogenin 3 (Ngn3) [70, 71].

The Hedgehog $(\mathrm{Hh})$ family of proteins controls cell growth, survival, and fate, and patterns almost every aspect of the vertebrate body plan [72]. The Hh family of proteins also plays a role in the maintenance of many adult structures that include proliferating cell populations [73]. Sonic hedgehog (Shh) is expressed throughout the embryonic gut tube, except for the pancreatic bud endoderm $[74,75]$. Forced expression of Shh from the Pdx1 promoter inhibits pancreatic development [74]. The Shh inhibitor cyclopamine expands the endodermal region where pdx 1 expression starts [76]. Thus, the absence of Shh provides a permissive condition leading to pancreatic specification. Reciprocal antagonism between $\mathrm{Hh}$ and RA signaling has been suggested [77].

In addition to RA, several other mesodermal signals are critical for patterning the embryonic endoderm into the pancreas. The notochord, the future backbone, is located proximal to the dorsal prepancreatic endoderm. Notochord-derived signals (fibroblast growth factor 2 (Fgf2) and Activin) can suppress endodermal Shh expression and initiate pancreatic differentiation $[75,78,79]$. After notochordal contact with the prepancreatic endoderm, endothelial signals from the nearby aorta promote further dorsal pancreatic specification $[80,81]$. The lateral plate mesoderm that lies beneath the ventral prepancreatic endoderm also sends instructive signals that establish the ventral pancreatic domain [82].

There is a bipotential precursor population for the pancreas and liver within the embryonic endoderm [83]. Bone morphogenetic protein (BMP) from cardiogenic mesoderm adjacent to the prehepatic endoderm induces hepatic genes and excludes the pancreatic fate $[84,85]$. BMP inhibition by Noggin or other inhibitors at this step is the common basis for the in vitro pancreatic differentiation protocols from ES/iPS cells [71, 86-91]. 


\section{Pancreatic epithelial cell growth and endocrine commitment}

The Fgf7 subfamily is unique among FGFs because its members (Fgf7, Fgf10, and Fgf22) are expressed exclusively in the mesenchyme and interact specifically with the Fgf receptor $2 b$ [92]. Fgf7 and 10 are expressed in the mesenchyme adjacent to the prepancreatic buds, and Fgf receptor $2 \mathrm{~b}$ is expressed in the pancreatic epithelium; addition of each fgf to organ cultures promotes the proliferation of pancreatic epithelial cells [93-95]. In the Fgf10-knockout mouse, pancreatic hypoplasia and the absence of islet cells are evident [93]. Conversely, transgenic overexpression of Fgf10 in Pdx1-expressing progenitor cells increases the proliferation of epithelial cells and blocks differentiation by activating Notch signaling $[95,96]$.

Notch signaling is known to be responsible for the maintenance of neuronal stem cell populations by inhibiting their differentiation [97]. Targeting of Notch pathway genes in mice results in the upregulation of Ngn3 and premature endocrine differentiation at the expense of progenitor cell proliferation, suggesting that activation of the pathway plays a role in maintaining the progenitor cell state in the early pancreatic epithelium [98-100]. Ngn3 is a basic helix-loop-helix transcription factor that regulates the development of hypothalamic neurons [101]. In the Ngn3-knockout mouse, all pancreatic endocrine cell lineages and endocrine cell-related transcription factors (such as Isl1, Pax4, Pax6, and NeuroD) are lost [102].

Conditional knockout mice lacking Smad4 (a common transcriptional coactivator in the pathway) in Pdx1expressing pancreatic progenitors can generate a normal pancreas, suggesting that TGF-beta/BMP signaling is dispensable after pancreatic commitment [103]. Inhibition of TGF-beta and BMP signaling has been reported to increase commitment to endocrine lineage [89].

\section{Pancreatic beta-cell differentiation and maturation}

A complex cascade of many transcription factors, such as Is11, Pax4, Pax6, NeuroD, Nkx2.2, Nkx6.1, Isl1, MafB, and MafA is involved in the differentiation and maturation of pancreatic beta-cells, but little is known about the extrinsic signals regulating this process [104]. Many differentiation protocols for inducing insulin-producing cells from human ES/iPS cells have been reported [71, 87-90, 105-110]. However, most insulin-producing cells generated are immature, produce multiple hormones and low levels of insulin, and have poor responses to secretory stimuli. In addition, all types of pancreatic cells, not just beta-cells, are differentiated at the same time in most protocols. Further studies are now trying to obtain more fully differentiated beta-cells in the presence of specific cues.

\section{Adipocyte transplantation}

In mammals, adipose tissue comprises white adipose tissue (WAT), primary site of energy storage and mobilization in the form of triglyceride and brown adipose tissue (BAT), which specializes in energy dissipation as thermogenesis.

Obesity is an excess adiposity and is linked to T2DM, cardiovascular, pulmonary, liver, and kidney diseases and certain types of cancer $[111,112]$. The anatomical distribution of WAT influences the risks associated with obesity. Obese individuals with a high waist-tohip ratio, indicating increased visceral fat, have a higher risk for metabolic abnormalities than do individuals with a low waist-to-hip ratio [113]. Subcutaneous fat differs intrinsically from visceral fat and is thought to protect from metabolic disorders [114].

Lipodystrophy is an abnormal loss of adiposity and is characterized by loss of body fat and insulin resistance [115]. Lipodystrophy is accompanied by diabetes mellitus, hypertriglyceridemia, and hepatic steatosis. Leptin treatment or transplantation of wild-type but not leptindeficient WAT rescued the phenotype of A-ZIP/F-1 lipodystrophic mice, suggesting that leptin deficiency is the major contributor to the metabolic complications of lipodystrophy [116-119]. Several studies have shown that intraperitoneal transplantation of WAT improves glucose tolerance and insulin sensitivity in mice with other conditions besides lipodystrophy [114, 120].

BAT is a major site of energy dissipation because of its high mitochondrial content; in BAT mitochondria, oxidative phosphorylation is uncoupled from adenosine triphosphate (ATP) production as a result of proton leak catalyzed by uncoupling protein 1 (UCP1) [121]. Studies of mice lacking BAT or UCP1 have demonstrated the ability of BAT thermogenesis to protect against diet induced obesity $[122,123]$. Transplantation of BAT into the visceral cavity in mice improved glucose tolerance, increased insulin sensitivity, reduced body weight and fat mass, and reversed high-fat diet-induced insulin resistance [124]. Recent studies have detected metabolically active BAT in the neck and upper thorax of normal humans [125].

Therapeutic adipogenesis is an exciting frontier of 
metabolic medicine, but our understanding of adipocyte development is still poor compared with that of pancreatic development $[38,39]$.

\section{Adipocyte development}

\section{White adipocytes}

White adipocytes can be generated from both mesoderm and neuroectoderm through mesenchymal stem cells (MSCs) [126]. MSCs are defined by plastic-adherent growth and the potential to give rise to multiple mesenchymal cell lineages including osteocytes, chondrocytes, and adipocytes $[127,128]$. MSCs reside in the vascular stroma of adipose tissue, the bone marrow and many other tissues [129, 130]. Several factors that commit or inhibit the conversion of MSCs to the adipocyte lineage have been identified. BMP-2 and -4 signaling supports white adipocyte differentiation [131-134]. Wnt signaling acts as an activator of lineage commitment from MSCs to white adipocytes and later as an inhibitor of the differentiation program [135-138]. Shh signaling has an inhibitory effect on adipocyte differentiation [139]. About 10\% of adipocytes are renewed annually at all adult ages in humans [140].

\section{Brown adipocytes}

BAT originates from the paraxial mesoderm [141]. Brown adipocytes and skeletal muscle develop from a common progenitor, which expresses Myf5 [142]. BMP-7 triggers commitment of progenitor cells to a brown adipocyte lineage by inducing the regulator PRD1-BF1-RIZ1 homologous domain containing 16 (PRDM16) and peroxisome proliferator-activated receptor (PPAR) -gamma-coactivator-1 alpha [143]. PRDM16 specifies the brown adipocyte lineage from the Myf5-expressing progenitors by activating the transcriptional function of PPAR-gamma and by suppressing myogenic factors [144, 145].

\section{Patient-derived iPS cells for mitochondrial disease modeling}

The ability to generate iPS cells from patients allows one to obtain genetically identical cells of clinical interest for pathogenesis modeling. Patient-specific iPS cell lines have been derived from individuals with several endocrine and metabolic diseases (Table 1). In some cases, in vitro differentiation of iPS cells to the affected cell types has been reported, and some of which successfully recapitulate disease-associated abnormalities.
A deeper understanding in cell differentiation and function will be needed for iPS cell-based disease modeling.

We recently generated iPS cells from patients with the $\mathrm{A} 3243 \mathrm{G}$ mitochondrial DNA (mtDNA) mutation (Mt-iPS cells) [146]. mtDNA is present inside mitochondria and codes for enzymes for ATP production [147]. In mtDNA disease, wild-type and mutant mtDNA coexist in the same cell in a state called heteroplasmy. The tRNA (Leu) A3243G mutation is observed frequently in mtDNA diseases and is associated with diabetes mellitus, hearing loss, and cardiomyopathy [148]. The mode of inheritance of mtDNA diseases is maternal because sperm-derived paternal mtDNA disappears during early embryogenesis, [149]. However, the penetrance of mtDNA disease is variable, and it is not possible to predict the phenotypes of a child from the mother's heteroplasmy level [150]. This is also the case for somatic cells: it is not possible to predict to which cell types the mutant mtDNA will dominantly migrate during development.

A striking feature of these Mt-iPS cells was their bimodal levels of heteroplasmy (Fig. 2). The mtDNA mutation frequencies decreased to undetectable levels in about half of the clones, whereas the levels of mutation heteroplasmy were higher in the other half of the clones compared with those in the patients' original fibroblasts. The mtDNA content did not differ significantly between mutation-free and mutation-rich Mt-iPS cells.

To date, there is no specific therapy or cure for mitochondrial diseases. Efforts to understand the mtDNA diseases have been hampered by the lack of a disease model. Mutation-rich Mt-iPS cells may provide a suitable source of cells for human mitochondrial disease modeling in vitro. In addition, mutation-free iPS cells could provide an unlimited supply of disease-free cells for autologous transplantation therapy.

\section{Acknowledgments}

This work was supported in part by a Grant-in-Aid for Scientific Research from the Ministry of Education, Culture, Sports, Science and Technology of Japan ; the Takeda Medical Research Foundation; Japan Foundation of Applied Enzymology.

\section{Disclosure}

No potential conflicts of interest were disclosed. 
Table 1 Endocrine-metabolic disease-specific iPS cells based on published literature

\begin{tabular}{|c|c|c|c|c|}
\hline Disease & Publication & Genetic cause & Age/Gender & $\begin{array}{c}\text { Differentiation into affected cell types: } \\
\text { Functional Analysis }\end{array}$ \\
\hline \multirow{2}{*}{ Type 1 diabetes } & {$[151]$} & Multifactorial & $42 \mathrm{y} /$ Female & ND \\
\hline & {$[152]$} & Multifactorial & 30y/Male, 32y/Male & Pancreatic endocrine cell \\
\hline Type 2 diabetes & {$[153]$} & Multifactorial & $68 \mathrm{y} /$ Female, $78 \mathrm{y} /$ Male & Insulin-producing cell \\
\hline Mitochondrial diabetes & [146] & Mitochondrial genome A3243G & 38y/Male, 46y/Female & ND \\
\hline Prader-Willi syndrome & {$[154]$} & Paternal deletion of chromosome $15 \mathrm{q} 11-\mathrm{q} 13$. & ND & ND \\
\hline Lesch-Nyhan syndrome & [151] & $\begin{array}{l}\text { Hypoxanthine phosphoribosyltransferase } 1 \\
\text { gene, heterozygous carrier }\end{array}$ & $34 \mathrm{y} /$ Female & ND \\
\hline \multirow{2}{*}{$\begin{array}{l}\text { Familial } \\
\text { hypercholesterolemia }\end{array}$} & [155] & $\begin{array}{l}\text { Autosomal dominant mutation in low } \\
\text { density lipoprotein receptor }\end{array}$ & Unknown & \multirow{2}{*}{$\begin{array}{l}\text { Hepatocyte: Impaired ability to } \\
\text { incorporate low density lipoprotein }\end{array}$} \\
\hline & {$[156]$} & $\begin{array}{l}\text { Low density lipoprotein receptor gene: } 5 \\
\text { kb deletion (FG381) }\end{array}$ & 14y/Male & \\
\hline \multirow{2}{*}{$\begin{array}{l}\text { X-linked } \\
\text { adrenoleukodystrophy }\end{array}$} & \multirow{2}{*}[157]{} & $\begin{array}{l}\text { ATP-binding-cassette transporter } \\
\text { superfamily D member } 1 \text { gene: deletion } \\
\text { from exon } 8 \text { to exon } 10 \text {, homozygous }\end{array}$ & 6y/Male & \multirow{2}{*}{$\begin{array}{l}\text { Oligodendrocyte: Excessive very } \\
\text { long chain fatty acids accumulation }\end{array}$} \\
\hline & & $\begin{array}{l}\text { ATP-binding-cassette transporter } \\
\text { superfamily D member } 1 \text { gene: deletion } \\
\text { from exon } 7 \text { to exon } 10 \text {, homozygous }\end{array}$ & $32 \mathrm{y} /$ Male & \\
\hline \multirow{2}{*}{$\begin{array}{l}\text { Glycogen storage disease } \\
\text { type } 1\end{array}$} & [158] & $\begin{array}{l}\text { Glucose-6-phosphate transporter gene: } \\
\text { c.1124-2A }>\mathrm{G}\end{array}$ & $7 \mathrm{y} /$ Male & Hepatocyte \\
\hline & [155] & ND & 25y/Male & $\begin{array}{l}\text { Hepatocyte: Excessive glycogen and } \\
\text { lipid accumulation and excessive } \\
\text { production of lactate }\end{array}$ \\
\hline \multirow{5}{*}{ Gaucher disease } & [151] & $\begin{array}{l}\text { Glucocerebrosidase gene: pAsn370Ser, } \\
\text { c.84-85insG, compound heterozygous }\end{array}$ & 20y/Male & ND \\
\hline & [159] & $\begin{array}{l}\text { Glucocerebrosidase gene: pAsn370Ser, } \\
\text { c.84-85insG, compound heterozygous }\end{array}$ & 20y/Male & Neuron \\
\hline & \multirow{3}{*}[160]{} & $\begin{array}{l}\text { Glucocerebrosidase gene: pAsn370Ser, } \\
\text { homozygous }\end{array}$ & Adult/ND & \multirow{3}{*}{$\begin{array}{l}\text { Monocyte/Macrophage, Neuron: } \\
\text { Reduced glucocerebrosidase } \\
\text { activity and accumulation of } \\
\text { glucosylsphingolipids }\end{array}$} \\
\hline & & $\begin{array}{l}\text { Glucocerebrosidase gene: p.Leu444Pro, } \\
\text { RecNcil, compound heterozygous }\end{array}$ & Infant/ND & \\
\hline & & $\begin{array}{l}\text { Glucocerebrosidase gene: p.Leu444Pro, } \\
\text { homozygous }\end{array}$ & $3 y / N D$ & \\
\hline Wilson's disease & {$[161]$} & $\begin{array}{l}\text { ATPase, } \mathrm{Cu}^{2+} \text { transporting, beta } \\
\text { polypeptide gene: p.Arg778Leu, } \\
\text { homozygous }\end{array}$ & Middle age/Male & $\begin{array}{l}\text { Hepatocyte: Defective copper } \\
\text { transport }\end{array}$ \\
\hline \multirow{2}{*}{ Crigler-Najjar syndrome } & {$[158]$} & $\begin{array}{c}\text { Uridine diphosphate } \\
\text { glucuronosyltransferase 1A1 gene: } \\
\text { p.Leu413Pro, homozygous }\end{array}$ & 19y/Female, 21y/Male & Hepatocyte \\
\hline & {$[155]$} & $\begin{array}{c}\text { Uridine diphosphate } \\
\text { glucuronosyltransferase 1A1 gene: } 13 \\
\text { bp deletion in exon2, homozygous }\end{array}$ & $2 \mathrm{~m} / \mathrm{Male}$ & ND \\
\hline \multirow{2}{*}{$\begin{array}{l}\text { Alpha 1-antitrypsin } \\
\text { deficiency }\end{array}$} & {$[155]$} & $\begin{array}{c}\text { Alpha 1-antitrypsin gene: p.Glu342Lys, } \\
\text { homozygous }\end{array}$ & $\begin{array}{c}\text { 16y/Male, } 55 \mathrm{y} / \text { Male, } \\
65 \mathrm{y} / \mathrm{Male}\end{array}$ & $\begin{array}{l}\text { Hepatocyte: Retention of misfolded } \\
\text { polymeric alpha } 1 \text {-antitrypsin } \\
\text { protein within the endoplasmic } \\
\text { reticulum }\end{array}$ \\
\hline & {$[162]$} & ND & $\begin{array}{c}\mathrm{m} / \text { Male, } 47 \mathrm{y} / \text { Female } \\
57 \mathrm{y} / \text { Female, } \\
61 \mathrm{y} / \text { Female, 64y/Female }\end{array}$ & Hepatocyte \\
\hline \multirow{2}{*}{ Tyrosinemia type 1} & [158] & $\begin{array}{l}\text { Fumarylacetoacetate hydrolase gene: } \\
\text { p.Gln64His, homozygous }\end{array}$ & 6y/Female & Hepatocyte \\
\hline & [155] & $\begin{array}{l}\text { Fumarylacetoacetate hydrolase gene: } \\
\text { p.Val166Gly, heterozygous }\end{array}$ & $2 \mathrm{~m} / \mathrm{Male}$ & ND \\
\hline $\begin{array}{l}\text { Progressive familial } \\
\text { hereditary Cholestasis }\end{array}$ & [158] & Multifactorial & $17 \mathrm{y} /$ Female & Hepatocyte \\
\hline
\end{tabular}

ND, not described 


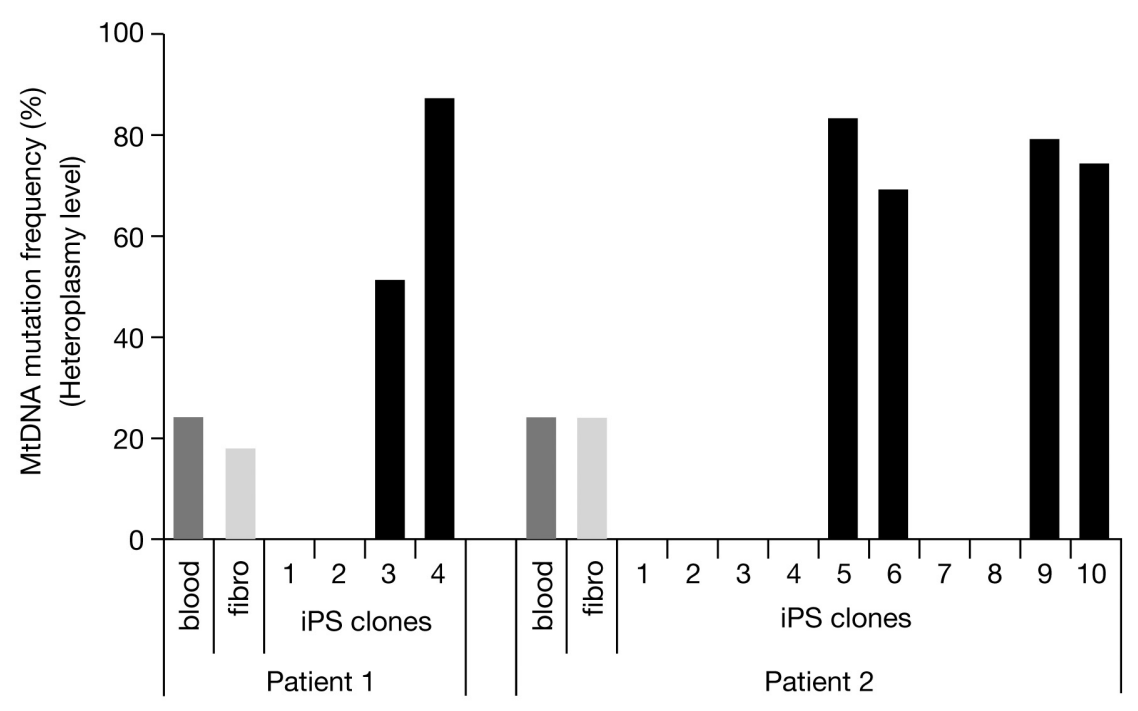

Fig. 2 mtDNA mutation frequencies in Mt-iPS cells

A3243G mtDNA mutation frequencies in the blood cells, original fibroblasts, and Mt-iPS clones from two diabetic patients with the A3243G mtDNA mutation.

\section{References}

1. Takahashi K, Tanabe K, Ohnuki M, Narita M, Ichisaka $\mathrm{T}$, et al. (2007) Induction of pluripotent stem cells from adult human fibroblasts by defined factors. Cell 131: 861-872.

2. Takahashi K, Yamanaka S (2006) Induction of pluripotent stem cells from mouse embryonic and adult fibroblast cultures by defined factors. Cell 126: 663-676.

3. Benedum J (1999) The early history of endocrine cell transplantation. J Mol Med (Berl) 77: 30-35.

4. Merani S, Shapiro AM (2006) Current status of pancreatic islet transplantation. Clin Sci (Lond) 110: 611-625.

5. Lindholm J, Laurberg P (2011) Hypothyroidism and thyroid substitution: historical aspects. J Thyroid Res 2011: 809341 .

6. Murray GR (1891) Note on the Treatment of Myxoedema by Hypodermic Injections of an Extract of the Thyroid Gland of a Sheep. Br Med J 2: 796-797.

7. Eknoyan G (1995) A history of the parathyroid glands. Am J Kidney Dis 26: 801-807.

8. Heller RS, Jenny M, Collombat P, Mansouri A, Tomasetto C, et al. (2005) Genetic determinants of pancreatic epsilon-cell development. Dev Biol 286: 217224.

9. (1995) U.K. prospective diabetes study 16. Overview of 6 years' therapy of type II diabetes: a progressive disease. U.K. Prospective Diabetes Study Group. Diabetes 44: 1249-1258.

10. Imamura M, Maeda S (2011) Genetics of type 2 diabetes: the GWAS era and future perspectives [Review]. Endocr $J$ 58: 723-739.
11. Sanghera DK, Blackett PR (2012) Type 2 Diabetes Genetics: Beyond GWAS. J Diabetes Metab 3: 6948.

12. Gepts W (1965) Pathologic anatomy of the pancreas in juvenile diabetes mellitus. Diabetes 14: 619-633.

13. Meier JJ, Bhushan A, Butler AE, Rizza RA, Butler PC (2005) Sustained beta cell apoptosis in patients with long-standing type 1 diabetes: indirect evidence for islet regeneration? Diabetologia 48: 2221-2228.

14. Butler AE, Janson J, Bonner-Weir S, Ritzel R, Rizza RA, et al. (2003) Beta-cell deficit and increased betacell apoptosis in humans with type 2 diabetes. Diabetes 52: 102-110.

15. Rahier J, Guiot Y, Goebbels RM, Sempoux C, Henquin JC (2008) Pancreatic beta-cell mass in European subjects with type 2 diabetes. Diabetes Obes Metab 10 Suppl 4: 32-42.

16. (1991) Epidemiology of severe hypoglycemia in the diabetes control and complications trial. The DCCT Research Group. Am J Med 90: 450-459.

17. Allen C, LeCaire T, Palta M, Daniels K, Meredith M, et al. (2001) Risk factors for frequent and severe hypoglycemia in type 1 diabetes. Diabetes Care 24: 18781881 .

18. (1998) Intensive blood-glucose control with sulphonylureas or insulin compared with conventional treatment and risk of complications in patients with type 2 diabetes (UKPDS 33). UK Prospective Diabetes Study (UKPDS) Group. Lancet 352: 837-853.

19. Kobayashi M, Yamazaki K, Hirao K, Oishi M, Kanatsuka A, et al. (2006) The status of diabetes control and antidi- 
abetic drug therapy in Japan - a cross-sectional survey of 17,000 patients with diabetes mellitus (JDDM 1). Diabetes Res Clin Pract 73: 198-204.

20. Meloche RM (2007) Transplantation for the treatment of type 1 diabetes. World J Gastroenterol 13: 63476355

21. Dieterle CD, Arbogast H, Illner WD, Schmauss S, Landgraf R (2007) Metabolic follow-up after long-term pancreas graft survival. Eur $J$ Endocrinol 156: 603610.

22. Paty BW, Lanz K, Kendall DM, Sutherland DE, Robertson RP (2001) Restored hypoglycemic counterregulation is stable in successful pancreas transplant recipients for up to 19 years after transplantation. Transplantation 72: 1103-1107.

23. Stratta RJ (2005) Surgical nuances in pancreas transplantation. Transplant Proc 37: 1291-1293.

24. Froud T, Ricordi C, Baidal DA, Hafiz MM, Ponte G, et al. (2005) Islet transplantation in type 1 diabetes mellitus using cultured islets and steroid-free immunosuppression: Miami experience. Am J Transplant 5: 20372046.

25. Ryan EA, Paty BW, Senior PA, Bigam D, Alfadhli E, et al. (2005) Five-year follow-up after clinical islet transplantation. Diabetes 54: 2060-2069.

26. Shapiro AM, Ricordi C, Hering BJ, Auchincloss H, Lindblad R, et al. (2006) International trial of the Edmonton protocol for islet transplantation. $N$ Engl J Med 355: 1318-1330.

27. Gerber PA, Pavlicek V, Demartines N, Zuellig R, Pfammatter T, et al. (2008) Simultaneous islet-kidney vs pancreas-kidney transplantation in type 1 diabetes mellitus: a 5 year single centre follow-up. Diabetologia 51: 110-119.

28. Posselt AM, Szot GL, Frassetto LA, Masharani U, Tavakol M, et al. (2010) Islet transplantation in type 1 diabetic patients using calcineurin inhibitor-free immunosuppressive protocols based on T-cell adhesion or costimulation blockade. Transplantation 90: 15951601

29. Balamurugan AN, Breite AG, Anazawa T, Loganathan G, Wilhelm JJ, et al. (2010) Successful human islet isolation and transplantation indicating the importance of class 1 collagenase and collagen degradation activity assay. Transplantation 89: 954-961.

30. Webb MA, Dennison AR, James RF (2012) The potential benefit of non-purified islets preparations for islet transplantation. Biotechnol Genet Eng Rev 28: 101114.

31. Egawa H, Tanabe K, Fukushima N, Date H, Sugitani A, et al. (2012) Current status of organ transplantation in Japan. Am J Transplant 12: 523-530.

32. Yoshimura N, Okajima H, Ushigome H, Sakamoto S, Fujiki M, et al. (2010) Current status of organ transplantation in Japan and worldwide. Surg Today 40: 514-
525.

33. Huurman VA, Hilbrands R, Pinkse GG, Gillard P, Duinkerken G, et al. (2008) Cellular islet autoimmunity associates with clinical outcome of islet cell transplantation. PLoS One 3: e2435.

34. Burke GW, 3rd, Vendrame F, Pileggi A, Ciancio G, Reijonen H, et al. (2011) Recurrence of autoimmunity following pancreas transplantation. Curr Diab Rep 11: 413-419.

35. Sutherland DE, Goetz FC, Sibley RK (1989) Recurrence of disease in pancreas transplants. Diabetes 38 Suppl 1: 85-87.

36. Murry CE, Keller G (2008) Differentiation of embryonic stem cells to clinically relevant populations: lessons from embryonic development. Cell 132: 661-680.

37. Sasai Y (2013) Cytosystems dynamics in self-organization of tissue architecture. Nature 493: 318-326.

38. Nostro MC, Keller G (2012) Generation of beta cells from human pluripotent stem cells: Potential for regenerative medicine. Semin Cell Dev Biol 23: 701-710.

39. Sarjeant K, Stephens JM (2012) Adipogenesis. Cold Spring Harb Perspect Biol 4: a008417.

40. Pearse AG (1969) The cytochemistry and ultrastructure of polypeptide hormone-producing cells of the APUD series and the embryologic, physiologic and pathologic implications of the concept. J Histochem Cytochem 17: 303-313.

41. Lecoin L, Rocques N, El-Yakoubi W, Ben Achour S, Larcher M, et al. (2010) MafA transcription factor identifies the early ret-expressing sensory neurons. Dev Neurobiol 70: 485-497.

42. Portela-Gomes GM, Hacker GW, Weitgasser R (2004) Neuroendocrine cell markers for pancreatic islets and tumors. Appl Immunohistochem Mol Morphol 12: 183192.

43. Andrew A, Kramer B (1979) An experimental investigation into the possible origin of pancreatic islet cells from rhombencephalic neurectoderm. $J$ Embryol Exp Morphol 52: 23-38.

44. Fontaine J, Le Lievre C, Le Douarin NM (1977) What is the developmental fate of the neural crest cells which migrate into the pancreas in the avian embryo? Gen Comp Endocrinol 33: 394-404.

45. Pearse AG (1979) The diffuse endocrine system and the implications of the APUD concept. Int Surg 64: 5-7.

46. Pictet RL, Rall LB, Phelps P, Rutter WJ (1976) The neural crest and the origin of the insulin-producing and other gastrointestinal hormone-producing cells. Science 191: 191-192.

47. Lu CC, Brennan J, Robertson EJ (2001) From fertilization to gastrulation: axis formation in the mouse embryo. Curr Opin Genet Dev 11: 384-392.

48. Abe K, Niwa H, Iwase K, Takiguchi M, Mori M, et al. (1996) Endoderm-specific gene expression in embryonic stem cells differentiated to embryoid bodies. Exp 
Cell Res 229: 27-34.

49. Duncan SA, Navas MA, Dufort D, Rossant J, Stoffel M (1998) Regulation of a transcription factor network required for differentiation and metabolism. Science 281: 692-695.

50. Fujikura J, Yamato E, Yonemura S, Hosoda K, Masui S, et al. (2002) Differentiation of embryonic stem cells is induced by GATA factors. Genes Dev 16: 784-789.

51. Kwon GS, Viotti M, Hadjantonakis AK (2008) The endoderm of the mouse embryo arises by dynamic widespread intercalation of embryonic and extraembryonic lineages. Dev Cell 15: 509-520.

52. Yasunaga $M$, Tada S, Torikai-Nishikawa S, Nakano Y, Okada M, et al. (2005) Induction and monitoring of definitive and visceral endoderm differentiation of mouse ES cells. Nat Biotechnol 23: 1542-1550.

53. Kemp C, Willems E, Abdo S, Lambiv L, Leyns L (2005) Expression of all Wnt genes and their secreted antagonists during mouse blastocyst and postimplantation development. Dev Dyn 233: 1064-1075.

54. Liu P, Wakamiya M, Shea MJ, Albrecht U, Behringer RR, et al. (1999) Requirement for Wnt3 in vertebrate axis formation. Nat Genet 22: 361-365.

55. Haegel H, Larue L, Ohsugi M, Fedorov L, Herrenknecht K, et al. (1995) Lack of beta-catenin affects mouse development at gastrulation. Development 121: 35293537.

56. Zhou X, Sasaki H, Lowe L, Hogan BL, Kuehn MR (1993) Nodal is a novel TGF-beta-like gene expressed in the mouse node during gastrulation. Nature 361: 543547.

57. Vincent SD, Dunn NR, Hayashi S, Norris DP, Robertson EJ (2003) Cell fate decisions within the mouse organizer are governed by graded Nodal signals. Genes Dev 17: 1646-1662.

58. Wang P, Rodriguez RT, Wang J, Ghodasara A, Kim SK (2011) Targeting SOX17 in human embryonic stem cells creates unique strategies for isolating and analyzing developing endoderm. Cell Stem Cell 8: 335-346.

59. McLean AB, D'Amour KA, Jones KL, Krishnamoorthy M, Kulik MJ, et al. (2007) Activin a efficiently specifies definitive endoderm from human embryonic stem cells only when phosphatidylinositol 3-kinase signaling is suppressed. Stem Cells 25: 29-38.

60. Gadue P, Huber TL, Paddison PJ, Keller GM (2006) Wnt and TGF-beta signaling are required for the induction of an in vitro model of primitive streak formation using embryonic stem cells. Proc Natl Acad Sci U S A 103: 16806-16811.

61. Tada S, Era T, Furusawa C, Sakurai H, Nishikawa $\mathrm{S}$, et al. (2005) Characterization of mesendoderm: a diverging point of the definitive endoderm and mesoderm in embryonic stem cell differentiation culture. Development 132: 4363-4374.

62. D'Amour KA, Agulnick AD, Eliazer S, Kelly OG,
Kroon E, et al. (2005) Efficient differentiation of human embryonic stem cells to definitive endoderm. Nat Biotechnol 23: 1534-1541.

63. Kubo A, Shinozaki K, Shannon JM, Kouskoff V, Kennedy M, et al. (2004) Development of definitive endoderm from embryonic stem cells in culture. Development 131: 1651-1662.

64. Wells JM, Melton DA (1999) Vertebrate endoderm development. Annu Rev Cell Dev Biol 15: 393-410.

65. Wright CV, Schnegelsberg P, De Robertis EM (1989) XlHbox 8: a novel Xenopus homeo protein restricted to a narrow band of endoderm. Development 105: 787794.

66. Jonsson J, Carlsson L, Edlund T, Edlund H (1994) Insulin-promoter-factor 1 is required for pancreas development in mice. Nature 371: 606-609.

67. Offield MF, Jetton TL, Labosky PA, Ray M, Stein RW, et al. (1996) PDX-1 is required for pancreatic outgrowth and differentiation of the rostral duodenum. Development 122: 983-995.

68. Martin M, Gallego-Llamas J, Ribes V, Kedinger M, Niederreither K, et al. (2005) Dorsal pancreas agenesis in retinoic acid-deficient Raldh2 mutant mice. Dev Biol 284: 399-411.

69. Molotkov A, Molotkova N, Duester G (2005) Retinoic acid generated by Raldh2 in mesoderm is required for mouse dorsal endodermal pancreas development. Dev Dyn 232: 950-957.

70. Micallef SJ, Janes ME, Knezevic K, Davis RP, Elefanty AG, et al. (2005) Retinoic acid induces Pdx1-positive endoderm in differentiating mouse embryonic stem cells. Diabetes 54: 301-305.

71. Cai J, Yu C, Liu Y, Chen S, Guo Y, et al. (2010) Generation of homogeneous PDX1(+) pancreatic progenitors from human ES cell-derived endoderm cells. $J$ Mol Cell Biol 2: 50-60.

72. Robbins DJ, Fei DL, Riobo NA (2012) The Hedgehog signal transduction network. Sci Signal 5: re6.

73. Beachy PA, Karhadkar SS, Berman DM (2004) Tissue repair and stem cell renewal in carcinogenesis. Nature 432: 324-331.

74. Apelqvist A, Ahlgren U, Edlund H (1997) Sonic hedgehog directs specialised mesoderm differentiation in the intestine and pancreas. Curr Biol 7: 801-804.

75. Hebrok M, Kim SK, Melton DA (1998) Notochord repression of endodermal Sonic hedgehog permits pancreas development. Genes Dev 12: 1705-1713.

76. Kim SK, Melton DA (1998) Pancreas development is promoted by cyclopamine, a hedgehog signaling inhibitor. Proc Natl Acad Sci U S A 95: 13036-13041.

77. Tehrani Z, Lin S (2011) Antagonistic interactions of hedgehog, Bmp and retinoic acid signals control zebrafish endocrine pancreas development. Development 138: 631-640.

78. Hebrok M, Kim SK, St Jacques B, McMahon AP, 
Melton DA (2000) Regulation of pancreas development by hedgehog signaling. Development 127: 4905-4913.

79. Hebrok M (2003) Hedgehog signaling in pancreas development. Mech Dev 120: 45-57.

80. Lammert E, Cleaver O, Melton D (2001) Induction of pancreatic differentiation by signals from blood vessels. Science 294: 564-567.

81. Kumar M, Melton D (2003) Pancreas specification: a budding question. Curr Opin Genet Dev 13: 401-407.

82. Kumar M, Jordan N, Melton D, Grapin-Botton A (2003) Signals from lateral plate mesoderm instruct endoderm toward a pancreatic fate. Dev Biol 259: 109-122.

83. Deutsch G, Jung J, Zheng M, Lora J, Zaret KS (2001) A bipotential precursor population for pancreas and liver within the embryonic endoderm. Development 128: 871-881.

84. Rossi JM, Dunn NR, Hogan BL, Zaret KS (2001) Distinct mesodermal signals, including BMPs from the septum transversum mesenchyme, are required in combination for hepatogenesis from the endoderm. Genes Dev 15: 1998-2009.

85. Shin D, Shin CH, Tucker J, Ober EA, Rentzsch F, et al. (2007) Bmp and Fgf signaling are essential for liver specification in zebrafish. Development 134: 20412050 .

86. Johannesson M, Stahlberg A, Ameri J, Sand FW, Norrman K, et al. (2009) FGF4 and retinoic acid direct differentiation of hESCs into PDX1-expressing foregut endoderm in a time- and concentration-dependent manner. PLoS One 4: e4794.

87. Zhang D, Jiang W, Liu M, Sui X, Yin X, et al. (2009) Highly efficient differentiation of human ES cells and iPS cells into mature pancreatic insulin-producing cells. Cell Res 19: 429-438.

88. Mfopou JK, Chen B, Mateizel I, Sermon K, Bouwens L (2010) Noggin, retinoids, and fibroblast growth factor regulate hepatic or pancreatic fate of human embryonic stem cells. Gastroenterology 138: 2233-2245, 2245. e1-14.

89. Kunisada Y, Tsubooka-Yamazoe N, Shoji M, Hosoya M (2012) Small molecules induce efficient differentiation into insulin-producing cells from human induced pluripotent stem cells. Stem Cell Res 8: 274-284.

90. Kroon E, Martinson LA, Kadoya K, Bang AG, Kelly OG, et al. (2008) Pancreatic endoderm derived from human embryonic stem cells generates glucose-responsive insulin-secreting cells in vivo. Nat Biotechnol 26: 443-452.

91. Ostrom M, Loffler KA, Edfalk S, Selander L, Dahl U, et al. (2008) Retinoic acid promotes the generation of pancreatic endocrine progenitor cells and their further differentiation into beta-cells. PLoS One 3: e2841.

92. Zhang X, Ibrahimi OA, Olsen SK, Umemori H, Mohammadi M, et al. (2006) Receptor specificity of the fibroblast growth factor family. The complete mamma- lian FGF family. $J$ Biol Chem 281: 15694-15700.

93. Bhushan A, Itoh N, Kato S, Thiery JP, Czernichow P, et al. (2001) Fgf10 is essential for maintaining the proliferative capacity of epithelial progenitor cells during early pancreatic organogenesis. Development 128 : 5109-5117.

94. Ye F, Duvillie B, Scharfmann R (2005) Fibroblast growth factors 7 and 10 are expressed in the human embryonic pancreatic mesenchyme and promote the proliferation of embryonic pancreatic epithelial cells. Diabetologia 48: 277-281.

95. Hart A, Papadopoulou S, Edlund H (2003) Fgf10 maintains notch activation, stimulates proliferation, and blocks differentiation of pancreatic epithelial cells. Dev Dyn 228: 185-193.

96. Norgaard GA, Jensen JN, Jensen J (2003) FGF10 signaling maintains the pancreatic progenitor cell state revealing a novel role of Notch in organ development. Dev Biol 264: 323-338.

97. Louvi A, Artavanis-Tsakonas S (2006) Notch signalling in vertebrate neural development. Nat Rev Neurosci 7: 93-102.

98. Apelqvist A, Li H, Sommer L, Beatus P, Anderson DJ, et al. (1999) Notch signalling controls pancreatic cell differentiation. Nature 400: 877-881.

99. Fujikura J, Hosoda K, Iwakura H, Tomita T, Noguchi $\mathrm{M}$, et al. (2006) Notch/Rbp-j signaling prevents premature endocrine and ductal cell differentiation in the pancreas. Cell Metab 3: 59-65.

100. Jensen J, Pedersen EE, Galante P, Hald J, Heller RS, et al. (2000) Control of endodermal endocrine development by Hes-1. Nat Genet 24: 36-44.

101. Pelling M, Anthwal N, McNay D, Gradwohl G, Leiter $\mathrm{AB}$, et al. (2011) Differential requirements for neurogenin 3 in the development of POMC and NPY neurons in the hypothalamus. Dev Biol 349: 406-416.

102. Gradwohl G, Dierich A, LeMeur M, Guillemot F (2000) neurogenin 3 is required for the development of the four endocrine cell lineages of the pancreas. Proc Natl Acad Sci US A 97: 1607-1611.

103. Bardeesy N, Cheng KH, Berger JH, Chu GC, Pahler J, et al. (2006) Smad4 is dispensable for normal pancreas development yet critical in progression and tumor biology of pancreas cancer. Genes Dev 20: 3130-3146.

104. Raducanu A, Lickert H (2012) Understanding pancreas development for beta-cell repair and replacement therapies. Curr Diab Rep 12: 481-489.

105. Ameri J, Stahlberg A, Pedersen J, Johansson JK, Johannesson MM, et al. (2010) FGF2 specifies hESCderived definitive endoderm into foregut/midgut cell lineages in a concentration-dependent manner. Stem Cells 28: 45-56.

106. D'Amour KA, Bang AG, Eliazer S, Kelly OG, Agulnick AD, et al. (2006) Production of pancreatic hormone-expressing endocrine cells from human embryonic stem 
cells. Nat Biotechnol 24: 1392-1401.

107. Jiang J, Au M, Lu K, Eshpeter A, Korbutt G, et al. (2007) Generation of insulin-producing islet-like clusters from human embryonic stem cells. Stem Cells 25: 1940-1953.

108. Micallef SJ, Li X, Schiesser JV, Hirst CE, Yu QC, et al. (2012) INS(GFP/w) human embryonic stem cells facilitate isolation of in vitro derived insulin-producing cells. Diabetologia 55: 694-706.

109. Rezania A, Riedel MJ, Wideman RD, Karanu F, Ao Z, et al. (2011) Production of functional glucagon-secreting alpha-cells from human embryonic stem cells. Diabetes 60: 239-247.

110. Xu X, Browning VL, Odorico JS (2011) Activin, BMP and FGF pathways cooperate to promote endoderm and pancreatic lineage cell differentiation from human embryonic stem cells. Mech Dev 128: 412-427.

111. Guh DP, Zhang W, Bansback N, Amarsi Z, Birmingham CL, et al. (2009) The incidence of co-morbidities related to obesity and overweight: a systematic review and meta-analysis. BMC Public Health 9: 88.

112. Braun S, Bitton-Worms K, LeRoith D (2011) The Link between the Metabolic Syndrome and Cancer. International Journal of Biological Sciences 7: 10031015.

113. Tchernof A, Despres JP (2013) Pathophysiology of human visceral obesity: an update. Physiol Rev 93: 359404.

114. Tran TT, Yamamoto Y, Gesta S, Kahn CR (2008) Beneficial effects of subcutaneous fat transplantation on metabolism. Cell Metab 7: 410-420.

115. Garg A (2011) Clinical review\#: Lipodystrophies: genetic and acquired body fat disorders. J Clin Endocrinol Metab 96: 3313-3325.

116. Gavrilova O, Marcus-Samuels B, Graham D, Kim JK, Shulman GI, et al. (2000) Surgical implantation of adipose tissue reverses diabetes in lipoatrophic mice. $J$ Clin Invest 105: 271-278.

117. Gavrilova O, Marcus-Samuels B, Leon LR, Vinson C, Reitman ML (2000) Leptin and diabetes in lipoatrophic mice. Nature 403: 850; discussion 850-851.

118. Colombo C, Cutson JJ, Yamauchi T, Vinson C, Kadowaki T, et al. (2002) Transplantation of adipose tissue lacking leptin is unable to reverse the metabolic abnormalities associated with lipoatrophy. Diabetes 51: 2727-2733.

119. Shimomura I, Hammer RE, Ikemoto S, Brown MS, Goldstein JL (1999) Leptin reverses insulin resistance and diabetes mellitus in mice with congenital lipodystrophy. Nature 401: 73-76.

120. Konrad D, Rudich A, Schoenle EJ (2007) Improved glucose tolerance in mice receiving intraperitoneal transplantation of normal fat tissue. Diabetologia 50: 833839.

121. Himms-Hagen J (1990) Brown adipose tissue thermogenesis: interdisciplinary studies. FASEB J 4: 2890-
2898.

122. Hamann A, Flier JS, Lowell BB (1998) Obesity after genetic ablation of brown adipose tissue. $Z$ Ernahrungswiss 37 Suppl 1: 1-7.

123. Kontani Y, Wang Y, Kimura K, Inokuma KI, Saito M, et al. (2005) UCP1 deficiency increases susceptibility to diet-induced obesity with age. Aging Cell 4: 147-155.

124. Stanford KI, Middelbeek RJ, Townsend KL, An D, Nygaard EB, et al. (2013) Brown adipose tissue regulates glucose homeostasis and insulin sensitivity. J Clin Invest 123: 215-223.

125. Cypess AM, Lehman S, Williams G, Tal I, Rodman D, et al. (2009) Identification and importance of brown adipose tissue in adult humans. $N$ Engl J Med 360: 15091517.

126. Takashima Y, Era T, Nakao K, Kondo S, Kasuga M, et al. (2007) Neuroepithelial cells supply an initial transient wave of MSC differentiation. Cell 129: 13771388.

127. Pittenger MF, Mackay AM, Beck SC, Jaiswal RK, Douglas R, et al. (1999) Multilineage potential of adult human mesenchymal stem cells. Science 284: 143-147.

128. Prockop DJ (1997) Marrow stromal cells as stem cells for nonhematopoietic tissues. Science 276: 71-74.

129. Covas DT, Panepucci RA, Fontes AM, Silva WA Jr., Orellana MD, et al. (2008) Multipotent mesenchymal stromal cells obtained from diverse human tissues share functional properties and gene-expression profile with CD146+ perivascular cells and fibroblasts. Exp Hematol 36: 642-654.

130. Tang W, Zeve D, Suh JM, Bosnakovski D, Kyba M, et al. (2008) White fat progenitor cells reside in the adipose vasculature. Science 322: 583-586.

131. Bowers RR, Lane MD (2007) A role for bone morphogenetic protein-4 in adipocyte development. Cell Cycle 6: 385-389.

132. Huang H, Song TJ, Li X, Hu L, He Q, et al. (2009) BMP signaling pathway is required for commitment of C3H10T1/2 pluripotent stem cells to the adipocyte lineage. Proc Natl Acad Sci U S A 106: 12670-12675.

133. Tang QQ, Otto TC, Lane MD (2004) Commitment of C3H10T1/2 pluripotent stem cells to the adipocyte lineage. Proc Natl Acad Sci U S A 101: 9607-9611.

134. Bowers RR, Kim JW, Otto TC, Lane MD (2006) Stable stem cell commitment to the adipocyte lineage by inhibition of DNA methylation: role of the BMP-4 gene. Proc Natl Acad Sci U S A 103: 13022-13027.

135. Ross SE, Hemati N, Longo KA, Bennett CN, Lucas PC, et al. (2000) Inhibition of adipogenesis by Wnt signaling. Science 289: 950-953.

136. Bowers RR, Lane MD (2008) Wnt signaling and adipocyte lineage commitment. Cell Cycle 7: 1191-1196.

137. Davis LA, Zur Nieden NI (2008) Mesodermal fate decisions of a stem cell: the Wnt switch. Cell Mol Life Sci 65: 2658-2674. 
138. Kang S, Bennett CN, Gerin I, Rapp LA, Hankenson KD, et al. (2007) Wnt signaling stimulates osteoblastogenesis of mesenchymal precursors by suppressing CCAAT/ enhancer-binding protein alpha and peroxisome proliferator-activated receptor gamma. J Biol Chem 282: 14515-14524.

139. Cousin W, Fontaine C, Dani C, Peraldi P (2007) Hedgehog and adipogenesis: fat and fiction. Biochimie 89: 1447-1453.

140. Spalding KL, Arner E, Westermark PO, Bernard S, Buchholz BA, et al. (2008) Dynamics of fat cell turnover in humans. Nature 453: 783-787.

141. Atit R, Sgaier SK, Mohamed OA, Taketo MM, Dufort $\mathrm{D}$, et al. (2006) Beta-catenin activation is necessary and sufficient to specify the dorsal dermal fate in the mouse. Dev Biol 296: 164-176.

142. Seale P, Bjork B, Yang W, Kajimura S, Chin S, et al. (2008) PRDM16 controls a brown fat/skeletal muscle switch. Nature 454: 961-967.

143. Tseng YH, Kokkotou E, Schulz TJ, Huang TL, Winnay JN, et al. (2008) New role of bone morphogenetic protein 7 in brown adipogenesis and energy expenditure. Nature 454: 1000-1004.

144. Kajimura S, Seale P, Kubota K, Lunsford E, Frangioni JV, et al. (2009) Initiation of myoblast to brown fat switch by a PRDM16-C/EBP-beta transcriptional complex. Nature 460: 1154-1158.

145. Kajimura S, Seale P, Spiegelman BM (2010) Transcriptional control of brown fat development. Cell Metab 11: 257-262.

146. Fujikura J, Nakao K, Sone M, Noguchi M, Mori E, et al. (2012) Induced pluripotent stem cells generated from diabetic patients with mitochondrial DNA A3243G mutation. Diabetologia 55: 1689-1698.

147. May-Panloup P, Chretien MF, Malthiery Y, Reynier P (2007) Mitochondrial DNA in the oocyte and the developing embryo. Curr Top Dev Biol 77: 51-83.

148. Finsterer J (2009) Manifestations of the mitochondrial A3243G mutation. Int J Cardiol 137: 60-62.

149. Sato M, Sato K (2011) Degradation of paternal mitochondria by fertilization-triggered autophagy in C. elegans embryos. Science 334: 1141-1144.

150. Shoubridge EA, Wai T (2007) Mitochondrial DNA and the mammalian oocyte. Curr Top Dev Biol 77: 87-111.

151. Park IH, Arora N, Huo H, Maherali N, Ahfeldt T, et al. (2008) Disease-specific induced pluripotent stem cells. Cell 134: 877-886

152. Maehr R, Chen S, Snitow M, Ludwig T, Yagasaki L, et al. (2009) Generation of pluripotent stem cells from patients with type 1 diabetes. Proc Natl Acad Sci US A 106: 15768-15773.

153. Ohmine S, Squillace KA, Hartjes KA, Deeds MC, Armstrong AS, et al. (2012) Reprogrammed keratinocytes from elderly type 2 diabetes patients suppress senescence genes to acquire induced pluripotency. Aging (Albany NY) 4: 60-73.

154. Chamberlain SJ, Chen PF, Ng KY, Bourgois-Rocha F, Lemtiri-Chlieh F, et al. (2010) Induced pluripotent stem cell models of the genomic imprinting disorders Angelman and Prader-Willi syndromes. Proc Natl Acad Sci US A 107: 17668-17673.

155. Rashid ST, Corbineau S, Hannan N, Marciniak SJ, Miranda E, et al. (2010) Modeling inherited metabolic disorders of the liver using human induced pluripotent stem cells. J Clin Invest 120: 3127-3136.

156. Cayo MA, Cai J, DeLaForest A, Noto FK, Nagaoka M, et al. (2012) JD induced pluripotent stem cell-derived hepatocytes faithfully recapitulate the pathophysiology of familial hypercholesterolemia. Hepatology 56: 21632171.

157. Jang J, Kang HC, Kim HS, Kim JY, Huh YJ, et al. (2011) Induced pluripotent stem cell models from X-linked adrenoleukodystrophy patients. Ann Neurol 70: 402409.

158. Ghodsizadeh A, Taei A, Totonchi M, Seifinejad A, Gourabi H, et al. (2010) Generation of liver disease-specific induced pluripotent stem cells along with efficient differentiation to functional hepatocyte-like cells. Stem Cell Rev 6: 622-632.

159. Mazzulli JR, Xu YH, Sun Y, Knight AL, McLean PJ, et al. (2011) Gaucher disease glucocerebrosidase and alpha-synuclein form a bidirectional pathogenic loop in synucleinopathies. Cell 146: 37-52.

160. Panicker LM, Miller D, Park TS, Patel B, Azevedo JL, et al. (2012) Induced pluripotent stem cell model recapitulates pathologic hallmarks of Gaucher disease. Proc Natl Acad Sci U S A 109: 18054-18059.

161. Zhang S, Chen S, Li W, Guo X, Zhao P, et al. (2011) Rescue of ATP7B function in hepatocyte-like cells from Wilson's disease induced pluripotent stem cells using gene therapy or the chaperone drug curcumin. Hum Mol Genet 20: 3176-3187.

162. Somers A, Jean JC, Sommer CA, Omari A, Ford CC, et al. (2010) Generation of transgene-free lung diseasespecific human induced pluripotent stem cells using a single excisable lentiviral stem cell cassette. Stem Cells 28: 1728-1740. 